\title{
A Jesuit Missio Castrensis in France at the End of the Sixteenth Century: Discipline and Violence at War
}

\author{
Ariane Boltanski \\ Université de Rennes 2 \\ ariane.boltanski@univ-rennes2.fr
}

\begin{abstract}
France was a crucial testing ground for the Counter-Reformation conduct of war. In 1590-92, the Holy League appeared a receptive field for the model of an ideal "Christian soldier," and a Jesuit apostolate to an army at war and some examples of missio castrensis were therefore attempted in France, or in close contact with French battlefields. In particular, a Jesuit mission was established for the papal troops sent to support the Duke of Mayenne (1554-1611), and the Holy League. An earlier Jesuit mission to the troops of Alessandro Farnese in the Low Countries served as an inspiration to the Leaguers, the more so as on two occasions he led his soldiers into France to help them. As shown in numerous writings coming from the radical and urban circles of the League, as well as from the clergy engaged alongside the soldiers and urban militias in certain towns, the Christian soldier model was welcomed. However, no formal religious service was introduced within Mayenne's army, and the Jesuit project ended in failure, largely because the expected discipline and moral reform of soldiers' behavior failed to materialize. The failure of the mission is equally highlighted by the levels of violence during the war.
\end{abstract}

\section{Keywords}

France - Holy League - Wars of Religion - military chaplaincy - Jesuits - Antonio Possevino - Alessandro Farnese - Duke of Mayenne - Geronimo Matteucci - Jean de Caumont 
This article explores the diffusion of pastoral care for the soldiery in France in 1590-92. This religious project was adapted to the conduct of a Holy War and it was elaborated at the end of 156os, under the leadership of the Holy See with the essential support of the Society of Jesus. It consisted in an association between, on the one hand, a specific apostolate (the missio castrensis) largely confided to the Jesuits and, on the other, on the construction of an ideological model warrior that would have a major influence. I will term it the "Christian Soldier" model; indeed, it was largely formulated in a booklet by Antonio Possevino (1533-1611), Il Soldato christiano, printed in 1569 for the Catholic military campaign in France. In the following years, the goal of Christianizing armies in the field spread across Europe, and even beyond, and at the end of the sixteenth century we can observe an acceleration in the diffusion of this "Christian Soldier" model. Initially designed as a tool to make the papal armies more efficient in the struggle for the destruction of the enemies of the church and the faith, the project of the Christian soldier influenced the conduct of war through a series of unrelated initiatives, especially within the Spanish armies engaged on various fronts of war in Europe. ${ }^{1}$

As part of this process, late-sixteenth-century France appears to be a key field of experimentation for the Counter-Reformation model of war. I will attempt to clarify why and how. Henri Iv became king of France on August 2, 1589. He was supported by a "royalist" party that included Protestants and many Catholics. The kingdom was in the throes of war (the eighth civil war): on both sides, the Catholic League and the royalist party, the military forces were composite, combining French and foreign troops. As I will explain below, during the years 1590-92, the duke of Mayenne (1554-1611), general lieutenant of the League and supreme commander of the Holy Union forces, received military assistance from both the pope and the king of Spain, Philip II (r.1556-98), mostly through support provided by the governor of the Low Countries, Alessandro Farnese (1545-92). Thus, France was a privileged place for an international confessional confrontation between Catholics and Protestants, and consequently a particularly fertile ground for testing the Christian soldier model.

Clearly, the attempted religious reformation of the culture and practice of warfare can be associated with a process of "disciplining," which the church

1 For more references see Ariane Boltanski, “Forger le 'soldat chrétien': L'encadrement catholique des troupes pontificales et royales en France en 1568-1569," Revue historique 669 (2014): 51-85; Vincenzo Lavenia, Il catechismo dei soldati: Guerra e cura d'anime in età moderna (Bologna: Edb, 2014); Gianclaudio Civale, "La Compagnia di Gesù, la guerra e l'immagine del soldato da Ignazio a Possevino (1546-1569)," Società e storia 140 (2013): 283-317. 
aspired to extend to all aspects of social life. The first step was to subject the troops to this process according to the Tridentine recommendations. This was initially a project aimed particularly at commanding officers, that is, the nobility, which, at the time, played the leading role in the conduct of war. But, in this period, the disciplinary model was still subordinated to the overriding objective of the efficient military elimination of heretics and infidels. The French battlefield must be interpreted as a part of this wider conflict. The "Christian soldier" model can also be understood as an instance of legitimization: it categorized the struggle to eliminate heretics and infidels as a Holy War, that is in a "just war." The model furthermore included a praxis aiming to reform military behavior, to turn "glory-seeking knights" into Christ's soldiers willing to sacrifice their lives for a superior interest, that of vanquishing the enemies of the "True Faith," a victory which only God can grant. Its goal was to increase the efficiency of the Catholic armies for the benefit of the church and the propagation of the Faith. ${ }^{2}$ The Catholic League would prove very receptive to this crusading spirit. According to its more radical theorists, the League's very purpose was to defend God and his church against heresy and the Antichrist. ${ }^{3}$

I will attempt to examine to what extent the League culture constituted a receptive space for the "Christian Soldier" model and, more generally, how the Jesuit apostolate turned to the fighters then engaged in France as a new terrain for proselytism. As we will see, the Society's pastoral project would encounter severe limitations in practice.

\section{Between Rome, France, and Flanders}

A new attempt to implant a missio castrensis within the same framework as the seminal French Jesuit mission of 1569 , albeit including important evolutions, took place in the French kingdom in 1591-92. In order to support the Duke of Mayenne and the Holy League, Pope Gregory XIV (r.1590-91) sent to France an army made up of one thousand horsemen (forming ten companies) and two

2 See Ariane Boltanski, "Une langue religieuse de la guerre: De quelques manuels jésuites à l'intention des soldats dans la seconde moitié du $\mathrm{XVI}^{\mathrm{e}}$ siècle," in Les mots de la guerre dans l'Europe de la Renaissance, ed. Marie-Madeleine Fontaine and Jean-Louis Fournel (Geneva: Droz, 2016), 3:169-96.

3 Denis Crouzet, Les guerriers de Dieu: La violence au temps des troubles de religion, vers 1525 - vers 1610 (Seyssel: Champ Vallon, 2009 [1 $1^{\text {st }}$ ed. 1990]), ch. 17; Robert Descimon and José Javier Ruiz Ibáñez, Les ligueurs de l'exil: Le refuge catholique français après 1594 (Seyssel: Champ Vallon, 2005); Tatiana Debaggi Baranova, À coups de libelles: Une culture politique au temps des guerres de religion (1562-1598) (Geneva: Droz, 2012). 
thousand Italian infantrymen (also in ten companies), plus six thousand Swiss soldiers recruited from the Catholic cantons, especially Lucerne (although numbers actually in the field were surely lower). ${ }^{4}$ The chief general of this papal army was Ercole Sfondrati, duke of Montemarciano (1559-1637), the pope's nephew. The troops were under the spiritual supervision of a Jesuit chaplaincy and the superior guardianship of a pontifical commissioner, Geronimo Matteucci, bishop of Sarno (1544-1609). Gregory XIV was thus renewing a religious project widely deployed in the French context in 1569 . The Jesuit missionaries, as well as the bishop of Sarno, received their instructions in May, $1591 .^{5}$

A comparison between the instructions addressed to the Jesuits in 1591 and those drawn up probably by Possevino himself for the fathers sent to France in 1569 (at the time the first of their kind) reveals a certain degree of evolution in the Jesuit pastoral methods tailored to the specific field of military missions. ${ }^{6}$ As the Jesuits had to adjust to the particular characteristics of the missio castrensis and to build a pastoral care adapted to army life, to the ultimate priority of fighting for God's cause, if necessary until death, and at the same time to promote a reform of warlike practices and the culture of soldiers, and more specifically of the noble officers, this project was progressive and had to adapt to the different war contexts they encountered during the sixteenth and even more in the seventeenth century. The instructions, then, are an essential key to highlighting the concrete elaboration of this expertise, which was only partially theorized. The instructions always specify who is in overall charge of the mission to the troops (Curzio Amodei in 1569; Thomas Sailly, 1553-1623, for the mission to the army of Flanders, as indicated in the instructions established by François Coster, $153^{-1619}$, in $1588 ;^{7}$ Ippolito Panciroli in France in 1591). The instructions also name his closest assistants (in 1591 the admonitor was Peter

4 Archivum Secretum Vaticanum [hereafter Asv], Miscellanea, Arm., I, 24, ff. 129-31, instructions to Matteucci (May 1, 1591); Arm., I, 24, ff. 366-68, account (November 11, 1591); Arm., I, 24, ff. 414-16, recruitment of the Swiss contingent. See, Ivan Cloulas, "Larmée pontificale de Grégoire XIV, Innocent IX et Clément VIII, pendant la seconde campagne en France d'Alexandre Farnèse (1591-1592)," Bulletin de la Commission Royale d'Histoire 126 (1960): 83-102, here 84.

5 ASv, Miscellanea, Arm., I, 24, ff. 129-31, May 1, 1591; Cloulas, "L'armée pontificale," 84.

6 Archivum Romanum Societatis Iesu [hereafter ARSI], Inst.117-II, ff. 512-15, May 1591; another copy in ARSI, Inst. 188, ff. 266-69; see Giampiero Brunelli, Soldati del papa: Politica militare e nobiltà nello Stato della Chiesa (Rome: Carocci, 2003), 22; about the instructions for the Jesuits going to France in 1569, see notably Boltanski, "Forger": 63, 66-67.

7 ARSI, Inst. 117-II, ff. 517-18, "Ordinationes pro missione castrensi"; see Vincenzo Lavenia, "Non arma tractare sed animas': Cappellani cattolici, soldati e catechesi di guerra in età moderna," Annali di storia dell'esegesi 26 (2009): 47-100, here 78; Silvia Mostaccio, "La mission militaire jésuite auprès de l'armée des Flandres pendant la guerre de Trente Ans: Conversions 
Bracanius), and what their roles are. After 1569, the instructions become clearer about the hierarchy, on the one hand submitting the fathers to their superior and, on the other, the mission to the camp as a whole to the Society's authorities. After the general of the Society, missionaries depend on the provincial of the nearest province and on the nearest college rector, but as the mission was mobile and followed the army, the last link in the hierarchy was fluid. In 1569 as well as in 1591, the main goal assigned to the mission was the shaping of a Christian soldier. The instructions of 1591 indicated that the first purpose of the Jesuit apostolate was to "urge the soldiers to fight courageously for the Catholic Religion occupying the outposts of our Holy Mother, the Church." From one missio castrensis to another, the purposes of the project to discipline the army emerge in more and more detail, focusing on the fight against blasphemy, the repression of sins and vices like gambling, the pacification of quarrels, the necessity of confessions, the celebration of Masses, and public sermons. We also notice some changes: in 1591, the Jesuits are no longer directly in charge of the field hospital, a task which had proved especially gruelling and unmanageable in 1569, but they were still expected to assist the sick, the wounded, and those condemned to death. After 1569 , the instructions deal more concretely with the life of the Jesuits in the camp: in those of 1591 one can read specific rules governing food and rest. The Jesuit in fact must take care to eat and sleep sufficiently to be able to sustain their mission. For some aspects of material life, such as their horses or food supply, fathers may employ secular servants. Several articles of these later instructions are devoted to the relations with the commanding authorities on the camp, suggesting maintaining a certain distance in their dealings with the officers and men. As explained in the 1591 instructions, the main purpose is to preserve the image of the Society, which must "spread everywhere a holy perfume." Besides, it is stipulated that the Jesuits should not interfere with the business of the magistrates and princes. This recommendation is in line with the efforts of Claudio Acquaviva (in office, 1581-1615), who in the 1590s attempted to remove the Jesuits from any involvement in the political affairs of the time. ${ }^{8}$ As indicated by the 1591 instructions, the fathers in the camp will not behave as courtiers but they will try to invite

et sacrements," in Religion et piété au défi de la guerre de Trente Ans, ed. Bertrand Forclaz and Philippe Martin (Rennes: Pur, 2015), 183-202.

8 John L. McCarthy, S.J., Martin D. O'Keefe, S.J., and John W. Padberg, S.J., eds., For Matters of Greater Moment: The First Thirty Jesuit General Congregations; A Brief History and a Translation of the Decrees (St. Louis, MO: Institute of Jesuit Sources, 1994); A. Lynn Martin, Henri III and the Jesuit Politicians (Geneva: Droz, 1973); Sabina Pavone, I gesuiti dalle origini alla soppressione: 1540-1773 (Rome-Bari: Laterza, 2004), 39-42. 
the noble officers to a greater degree of piety in so far as "this can be useful to the Holy Church." ${ }^{\prime 9}$ The Jesuits will not share the meals of soldiers and officers; they will not be severe in the repression of vices; their sermons will not explicitly name individuals. They should also avoid celebrating Mass for the captains and the commanders (a waste of time and a source of problems); but if asked to do so on feast days the fathers should not refuse. Finally, by the end of the sixteenth century, the idea of missio castrensis seems to conform more closely to that of missions in general, in terms of advice for the fathers, "facultates" for the missionaries, and the areas of intervention. The 1591 instructions insist that the Jesuits must convert the soldiers by their example, particularly with regard to poverty. They should demonstrate the Christian virtues: purity, observance of God's commandments, humility, meekness, abnegation, disinterest in material goods, and above all charity. The practice of the Exercises will serve to strengthen the fathers in these virtues. The Jesuits have to live by alms, although in November 1591 the pontifical commissioner informs us that the cost for the six fathers is sixty écus a month. ${ }^{10}$ The instructions lay stress on the fact that the fathers must not gain money through their charges. They must show gravitas and temperance: no quarrelling with their companions, no hot-tempered reaction to the attacks of the enemies of the Society. If they are consulted on a case of conscience, they will take time to reflect, confer with one another, and agree on an answer; in fact, any differences would risk provoking denigration. As to the areas of intervention or "facultates" granted to them, in 1591 these are similar to those apportioned to the Jesuits in Italy, but with some peculiarities about the places of worship. The Jesuits can celebrate divine service inside tents and outdoors, that is, outside of churches, or even in deconsecrated buildings. The superior of the mission has the power to absolve his fellow Jesuits from reserved sins, if necessary.

The instructions given to Matteucci show some important differences compared to those given to the pontifical commissioner during the French mission of 1569. In fact, the papal agent no longer deals with religious questions, which suggests his greater specialization with troop management and financial issues, especially the distribution of pay to the soldiers, while Jesuit mission is more specifically in charge of the spiritual and moral care of the soldiers. ${ }^{11}$

During the years 1590-92, another example of a Jesuit missio castrensis may have inspired the Leaguers, encouraging a French adaptation of the "Christian soldier" model and of the pastoral care that went with it: this was the mission

9 ARSI, Inst. 117-II, ff. 512-15 (May 1591).

10 ASv, Miscellanea, Arm., I, 24, f. 377, to be paid every month.

11 ASv, Miscellanea, Arm., I, 24, ff. 129-31, instructions to Matteucci (May 1, 1591). 
alongside Alessandro Farnese's army in the Spanish Low Countries. Indeed, on two occasions the duke of Parma led his troops, experienced in combatting the Protestants in Flanders, to the rescue of the Holy League, which was then in a very difficult position. In August 1590, Farnese led between fifteen thousand and twenty thousand men (Spanish, Neapolitan, Walloon) into France to join the duke of Mayenne's troops and forced Henri IV to abandon the siege of Paris. ${ }^{12}$ In October 1590, again on the march, he launched a second expedition from December 1591 to mid-June 1592. This time, Farnese's army amounted to at least sixteen thousand men, and with the pontifical forces and the French contingents of the Holy League it took part in the liberation of Rouen besieged by the king in April 1592. ${ }^{13}$ The troops in Flanders, with those of the pope, are certainly among the first in Europe to be provided with a formal chaplaincy and a Jesuit mission, precisely on Farnese's initiative. On the one hand, the troops were assisted by ordinary chaplains in a framework institutionalized in 1579; on the other hand, from 1587 onwards, the army contained a Jesuit mission directed from Brussels by Sailly, a disciple of Antonio Possevino and Farnese's confessor. This was the first organized stable and long-term Jesuit missio castrensis. It would extend continuously until the 1630 s, with a break during the Twelve Years Truce. ${ }^{14}$ These two structures, the ordinary chaplaincy

12 José Javier Ruiz Ibáñez, Laberintos de hegemonía: La presencia militar de la monarquía hispánica en Francia a finales del siglo XVI (Valladolid: Universidad de Valladolid, 2012), 73. See Howell A. Lloyd, The Rouen Campaign, 1590-1592: Politics, Warfare and the Early Modern State (Oxford: Clarendon, 1973), 171; Léon van der Essen, Alexandre Farnèse: Prince de Parme, gouverneur général des Pays-Bas (1545-1592) (Bruxelles: Librairie Nationale d'Art et d'Histoire, 1933-37), 5:292-95. See a letter of the legato Caetani to Cardinal Montalto, August 15, 1590; a letter of Caetani to his brother, September 2, 1590 (Farnese had then thirteen thousand infantrymen and three thousand horsemen in service); a letter of Farnese to Caetani, October 23, 1590 (about his departure); all these letters (coming from the Archivio Caetani in Rome) are translated in Italian by G.-B. Caringi, "Sixte-Quint et la Ligue: Documents inédits," Revue du monde catholique 20 (1867): 783-809, here 799, 803, $807-8$.

13 ASv, Miscellanea, Arm., I, 24, ff. 293-95, here f. 294 (September 25, 1591); Arm., I, 24, ff. 337-42 (October 28, 1591); Arm., I, 24, ff. 357 (December 4, 1591); Lloyd, The Rouen Campaign, 172, 175; Van der Essen, Alexandre Farnèse, 349ff.; Cloulas, "L'armée pontificale," 94, 96.

14 See also Jean Schoonjans, “'Castra Dei': L'organisation religieuse des armées d'Alexandre Farnèse," in Miscellanea historica in honorem Leonis van der Essen (Bruxelles-Paris: Éditions Universitaires, 1947), 1:523-40, here 531, 533-34; Geoffrey Parker, The Army of Flanders and the Spanish Road, 1567-1659: The Logistics of Spanish Victory and Defeat in the Low Countries' Wars (Cambridge: Cambridge University Press, 1990), 171-72; Lavenia, "Non arma tractare sed animas," 79 . 
and the missio castrensis, ran parallel but totally separately. Originally financed by the duke of Parma, the Flemish mission included twenty-four Jesuits paid by the army in $1588 .{ }^{15}$ We do not know if Sailly personally took part in the French expeditions of Farnese, but his apostolate undoubtedly constituted a source of inspiration for the members of the Holy League, as shown by the presence of his manual for the Christian soldier in the duke of Mercœur's library at a later date. ${ }^{16}$ In fact, among the Catholic leaders, this prince was himself the best embodiment of the Christian soldier. ${ }^{17}$ In any case, Farnese contributed to importing into France some characteristics of Jesuit military pastoral care, the more so because he enjoyed immense prestige in many urban League factions, in particular in the most radical one, the Seize in Paris. For instance, Sailly had greatly expanded the devotion to the Virgin among the Catholic soldiers in Flanders: an image of the Virgin was embroidered on all the banners; every morning, the trumpets saluted Our Lady of the Victories. These initiatives, typical of the Jesuit apostolate, also reflected the personal devotion of the duke of Parma, deeply attached to both Eucharistic and Marian cults that he openly favored during the war in the Low Countries and later in France. Thus in 1590 Farnese promised the Parisians that he would deliver them for Assumption Day—a promise which he was not able to fulfill. ${ }^{18}$

\section{The True Noble as Christian Soldier and the Case of the French League Army}

On a more theoretical plane, the spirit of the League greatly favored the reception of the "Christian soldier" model. This reception is clearly present in the

15 Schoonjans, “Castra Dei," 537-39; Parker, Army of Flanders, 172.

16 Thomas Sailly, Guidon et pratique spirituelle du soldat chrétien (Anvers: Plantin, 1590). See Olivier Poncet, "Les lectures d'un chef de guerre catholique: Les livres de PhilippeEmmanuel de Lorraine, duc de Mercour (1558-1602) d'après l'inventaire du château de Nomény (1602)," in Le duc de Mercour: Les armes et les lettres (1558-1602), ed. Emmanuel Buron and Bruno Méniel (Rennes: Pur, 2009), 261-317, here 305.

17 Ariane Boltanski, "La haute noblesse catholique et la Ligue: Actions religieuses, fondations pieuses et engagements partisans," in La Sainte Union des catholiques de France et la fin des guerres de Religion (1585-1629), ed. Serge Brunet and José Javier Ruiz Ibáñez (Paris: Classiques Garnier, 2016), 401-20.

18 Schoonjans, "Castra Dei," 538, 540; Édouard Terwecoren, "Marie dans l'armée d'Alexandre Farnèse et l'œuvre des soldats," Collection de précis historiques 8 (1859): 393-95; JeanChrysostome Bruslé de Montpleinchamp, L'histoire d'Alexandre Farnèze, duc de Parme et de Plaisance, gouverneur de la Belgique (Amsterdam: A. Michils, 1692). 
Leaguers' reflections concerning the moral and religious discipline of soldiers and of the noblesse d'épée in the 1580 and 1590 . It is also evident in the antinobility polemics triggered at that time in the radical circles of the League, especially in Paris.

These polemics began with a treatise by the barrister Jean de Caumont, one of the leaders of the Parisian League, but they gained an unprecedented relevance in 1589 and even more in 1590 thanks to some pamphlets emanating from the Seize, such as those of the canon Mathieu de Launoy and Oudart Raynssant; in 1593, it was the turn of the Dialogue d'entre le maheustre et le manant. ${ }^{19}$ Beyond the League's straightforward adherence to the crusading spirit, this literature shows a clear assimilation of the Counter-Reformation ideal of warfare promoted since the 1560 os by the Society of Jesus. It would seem essential to compare these writings with the Jesuit military catechesis, though historians have not yet undertaken such a project. ${ }^{20}$

Destined soon to become a Leitmotiv of these propaganda writings, anti-nobility radical criticism is founded on the idea that the nobility has degenerated because of its contact with heresy to the point of losing its virtue (vertu). At the basis of this reflection lies the syllogism devised by Jean de Caumont: Nobility is vertu as a personal achievement, and is not therefore hereditary. Vertu equals ardor in defence of God's honor. Consequently, someone who does not defend God's honor is not a noble: "who is not virtuous cannot be noble." ${ }^{21}$ Caumont restates the fundamental premises of nobility, formulated in many treatises and writings devoted to noblemen during the sixteenth century: a noble is one who professes vertu (martial virtues and valor in war), which is also recognized as hereditary, transmitted by blood. This noble virtue is realized in action, in warlike exploits. Thus conceived, valor is perfectly

19 Jean de Caumont, De la vertu de noblesse aux roys et princes tres-chrestiens (Paris: Morel, 1585); Mathieu de Launoy, Remonstrance contenant une instruction Chrestienne de quatre poincts à la noblesse de France (Paris: Nivelle, 1590); Oudart Raynssant, Représentation de la noblesse hérétique sur le théâtre de France (Paris: Bichon, 1591); François Cromé, Dialogue d'entre le maheustre et le manant, ed. Peter Ascoli (Geneva: Droz, 1977); see also Aguillon aux vrays François pour la liberte des catholiques (n.p.: s.l. 1589), and for the Parisian Leaguer pamphlets, see Denis Pallier, Recherches sur l'imprimerie à Paris pendant la Ligue, 1585-1594 (Geneva: Droz, 1975), 182-83 and the inventory.

20 Some historians have focused on the question concerning the persistence of the Society for orders: Roland Mousnier, Arlette Jouanna, Denis Crouzet, Manfred Orlea, Peter Ascoli, Robert Descimon. See Élie Barnavie and Robert Descimon, La Sainte Ligue, le juge et la potence: L'assassinat du président Brisson, 15 novembre 1591 (Paris: Hachette, 1985), 255-59.

21 Caumont, De la vertu, 3-5. See also Exhortation derniere à la noblesse, pour la delivrance de nostre Roy tres-Chrestien (Paris: Hury, 1589), 19. 
compatible with God's service, but one cannot be identified with the other. ${ }^{22}$ Such is no longer the case in the vision of the radical Leaguers. Caumont opposes any identification of warlike courage (described as a kind of rage) with vertu. Through a semantic displacement, the Leaguers identify vertu with Christian virtue, and confuse it with an ardor to defend God's honor that includes waging war. As explained by these authors in opposition to the traditional idea of noble identity, nobility should not be limited to mere warlike valor, seeking heroic deeds, whatever their aims. Valor is not discredited as such, but only insofar as it encourages fighting without motive. From the Leaguers' point of view, the only legitimate fight is that against heresy and its associates. ${ }^{23}$ "True nobility," as Launoy and Caumont explain, is achieved in "the fight between vice and virtue,"24 that is in the spiritual fight opposing God and the Devil, a theme which lies at the heart of the Jesuit handbooks for the Christian soldier, like those of Auger, Possevino, and Sailly himself. These handbooks alter the tradition of spiritual fighting as presented in the scriptures and in a long string of theological writings on the "here and now" of war. They inextricably unite two fights: one inside the soldier's soul against his vices, invisible emissaries of Satan, and the other, external and warlike, against heretics and infidels, visible allies of the Devil. ${ }^{25} \mathrm{~A}$ soldier of Christ is fully justified when he kills God's enemies. Giving up the quest for mundane glory and heroic deeds to pursue God's glory, the soldier will receive the palm of martyrdom in return for his possible sacrifice, and enter "the abode of Eternity." But to enjoy the support of God-a necessary condition to attain victory against heretics and infidels - the warrior must behave as a Christian soldier. This quasi conversion is achieved through ascetic behavior induced by the religious control of the troops, a tutoring largely based on the struggle against vices and the practice of Christian virtue, which ought to be fundamentally the same as the vertu of the noblesse d'épée.

In the first Jesuit catechesis of war, as in the writings of the radical Leaguers, this spiritual and devotional ideal thus presented to the warlike nobility is not conceived as independent from the military involvement against heresy. The Leaguers' main objective is to rally the Catholic nobility, diverting it away from the Béarnais party and offering to it a moral and religious model

22 See the works of Arlette Jouanna, in particular L'idée de race en France au XVI ${ }^{e}$ siècle et au début du XVII ${ }^{e}$, 1498-1614 (Paris: H. Champion, 1976), 2:625ff.

23 Caumont, De la vertu, 8; Aguillon aux vrays François, 44.

24 Launoy, Remonstrance, 10-11; Caumont, De la vertu, 6, 9-10.

25 See Boltanski, "Forger le 'soldat chrétien," 68-69; Boltanski, "Une langue religieuse de la guerre," $174-76$. 
of discipline appropriate to a militia Christi. For Caumont, a genuine nobleman cannot continue to commit the sin of blasphemy, a vice which the Jesuits strive to expel from the army. ${ }^{26} \mathrm{He}$ invites gentlemen to participate in charity and to reform their moral behavior. Like the Jesuit catechesis, referring to the Epistles of St. Paul, he points out the need to associate iron and spiritual weapons in the war to extirpate heresy. In this just war, the nobleman will achieve eternal salvation ("le guerdon éternel assuré en Dieu"): he need not be afraid because he is under God's protection. ${ }^{27}$ Like Launoy and other Leaguer authors, and like also some Jesuit handbooks, Caumont evokes the martyrs of the faith - a long sequence of crusading soldiers, princes and gentlemenwho have sacrificed themselves to defend religion: Saint Louis (r.1226-70), Charlemagne (r.80o-814), Godefroy de Bouillon (106o?-1100), Simon de Montfort (1165?-1218). ${ }^{28}$ The writings of the Leaguers still rely on other sources, also exploited by the Jesuit catechesis, like Italian and Spanish spiritual literature, with theological and historical works related to the ideal of the Crusade.

The image of the Christian soldier could also be found in another literary genre, favored by the Leaguers: the apologetic necrologies that we could term "tombstones," that is short pamphlets picturing officers of the League perished in action. ${ }^{29}$ In 1590 , after the battle of Ivry, a nobleman d'épée named Picaïne, then in Paris under siege, presented to the duke of Mayenne a project for a French militia, aiming at the total reorganization of the Holy League's army. The author expresses the wish to constrain the nobility to a moral and Christian regeneration through "the re-establishment of the ancient military discipline" fully conforming to that recommended by the Jesuit handbooks. ${ }^{30}$ Finally, the Leaguer Monarchomach treatise attributed to Guillaume Rose, bishop of Senlis (1542-1602), also demands a reformation of the warlike nobility, too frequently corrupted by impiety or heresy, proposing its reshaping on the lines of the chivalric orders. ${ }^{31}$ In 1588 , the bishop was advocating the

\footnotetext{
26 Caumont, De la vertu, 9, 24.

27 Ibid., 23-25.

28 Ibid., 10, 26-27; Launoy, Remonstrance, 15-16, 20; Aguillon aux vrays François, 41, 43.

29 See Le tombeau de hault et puissant seigneur Jean-Loïs de La Roche Foucault, comte de Randan (Paris: Delas, 159o); Pallier, Recherches sur l'imprimerie, 376.

30 De Picaïne, La Nouvelle milice françoise par où sont déduits les moyens d'ordonner l'infanterie catholique (Paris: Thierry, 1590), 76. On the need to discipline the soldiers and to improve their morality, see also the sonnet "Le devoir et gouvernement du vray gendarme" at the end of Reddition et prinse de la Ville et Chasteau d'Alençon (Paris: Grégoire, 1589).

31 De justa Reipublicae Christianae in reges impios et haereticos authoritate liber (Paris: Bichon, 1590); Jouanna, L'idée de race, 3:1250.
} 
development of a militia in Senlis, and in May 1590 he conducted a procession of the League through Paris in which regular clerics, priests and young students of the capital paraded with arms and armor (a true "march for crusade," according to Crouzet). ${ }^{32}$

These different writings testify to the reception and appropriation of the Counter-Reformation warlike culture by the Holy League. But the authors we have just evoked are mainly clerics, or connected with the legal professions (barristers in the case of Caumont and Raynssant); and with the exception of Picaïne, they are neither noble nor soldiers. It is far from certain that the aspirations of urban and/or radical Leaguers to discipline and regenerate the Christian warring nobility were shared by the noble leaders of the League themselves. The absence, in fact, of any structured apostolate for the disparate French forces within the League's army leads us to suspect that there may have been an internal fracture within the League, between the radicalism of the clerics and/or the urban affiliates to the League on one side, and the noble military command on the other.

On the basis of the documents known to me, the forces under the supreme authority of Mayenne were not provided with an organized mission nor probably with a structured chaplaincy. This does not mean, however, that some clerics were not active on the battlefield alongside the French soldiers in the 1590s. But the absence of religious institutional control may be a consequence of the composition of this army. Following the quasi-complete destruction of the League army in the aftermath of the battle of Ivry (March 14, 1590), Mayenne restored his forces by calling on reserve companies commanded by noble provincial leaders and by appealing to Philip II. The king of Spain compensated for his drained financial resources, by providing for most of the soldiers' pay and supplying Spanish troops to serve under Mayenne's command. Mayenne's army was thus eminently heterogeneous and volatile ${ }^{33}$ and this state of affairs did not favor the development of formalized religious guidance. Some members of the higher nobility in command positions in Mayenne's army undertook to set up pious foundations for the benefit of the militant orders of the Catholic Reformation at their own expense. As soon as the siege of Rouen came to an end, Mayenne himself made a large donation to the Capuchins of

\footnotetext{
32 Thierry Amalou, Le Lys et la Mitre: Loyalisme monarchique et pouvoir épiscopal pendant les guerres de Religion (1580-1610) (Paris: CT HS, 2007), 152-3, 252; Crouzet, Les guerriers, 2:395.

33 See, at the end of 1591, the description of the thirty-one companies of infantry and the 135 of cavalry on which Mayenne eventually could rely; all these companies are controlled by some noble Leaguer leaders: Asv, Miscellanea, Arm., I, 24, ff. 407-11.
} 
the city, who, during the siege, had upheld the League and had provided help to the population. ${ }^{34}$ However, I have not been able to detect any initiatives from these nobles towards establishing a system of religious care within the army in the spirit of the Counter-Reformation. The duke of Mercœur did appeal to the Capuchins to evangelize his troops, but this would take place much later, at the turn of the century, during his intervention in Hungary. ${ }^{35}$ The lack of resources, secular or ecclesiastical, experienced by the noble leaders of the French League troops may also provide an explanation for the lack of an organized apostolate for the soldiers in the 1590 .

In the towns controlled by the Holy League, the presence of regular and secular clerics, sometimes bearing arms, ${ }^{36}$ alongside garrisons, militias, and armed citizens, seems to have been a frequent occurrence, especially during sieges. The example of Paris is well known: Jesuits did not parade in the May 14 armed review; but some members of the college of Clermont (probably coadjutors and students) took part in the defense of the walls during the siege, consenting to bear arms, and were even responsible for the failure of a surprise attack by the royalists on September 9-10, 1590. Members of other religious orders, in particular mendicants, seem to have been more involved in armed demonstrations and in assisting the armed citizenry. ${ }^{37}$ Paris is not the only case; we might compare that of Chartres, where, during the siege (February-April 1591), some clerics assisted the soldiers who observed Lent, attended Mass, and confessed regularly. ${ }^{38}$ This can be interpreted as another proof of the reception of the "Christian soldier" model, again within an urban context. However this should be sharply distinguished from a structured chaplaincy integrated within a regular army.

34 Godefroy de Paris, Les Frères mineurs capucins en France: Histoire de la Province de Paris (Paris: Bibliothèque Franciscaine Provinciale, 1937-50), I/2:150-51.

35 Martin Fumée, Histoire générale des troubles de Hongrie et Transylvanie (Paris: Fouet, 16o8), 828 .

36 Following the papal authorization in September 1591: Bref de N. S. Pere le Pape Grégoire XIIII par lequel il est permis à tous ecclésiastiques de porter les armes contre les hérétiques (Paris: Nivelle, 1591); Pallier, Recherches sur l'imprimerie, 178.

37 Henri Fouqueray, Histoire de la Compagnie de Jésus en France, 5 vols. (Paris: Picard-Bureaux des Études, 1910-25), 2:234, 237-38; Ann Ramsey, Liturgy, Politics, and Salvation: The Catholic League in Paris and the Nature of Catholic Reform, 1540-1630 (Rochester: University of Rochester Press, 1999), 76-80, 122; see also above.

38 Histoire de Sébastien Le Pelletier, prêtre ligueur [...], 1579-1592, ed. Xavier Le Person (Geneva: Droz, 2006), 221-22. 
Has the Counter-Reformation model of warfare any practical application on the French battlefields in the 1590s? Does it succeed concretely in modifying military behavior? To a large extent, the answer to these questions is negative. The actual conduct of pro-League fighters between 1590 and 1592 is widely at variance with the "Christian soldier" model. In the field of religious and military discipline, the Jesuit apostolate is a complete failure, as it had been previously, in 1569, at the time of the first French missio castrensis. In my opinion, this is not only true of the French case. In the second half of the sixteenth century and in the first decades of the seventeenth century, this "embedded" missionary apostolate has to deal increasingly with the "irreducible constraints of reality," such as the troops' extortions and the violence of war. Most of the time, clerics are unable to turn warriors into Christian soldiers free from the vices associated with warfare. ${ }^{39}$ Between 1590 and 1592 , the gap that separates the Counter-Reformation model and the actual behavior of combatants appears to be the same within French troops devoid of any missionary work as within the papal contingent and the duke of Parma's army, both endowed with a formal Jesuit apostolate. Despite the large sums spent by the pope, the intervention of 1591-92 proves to be a total disaster. Unlike that of 1569 , the correspondence between the Jesuit missionaries and the general concerning the 1591-92 mission has not been preserved. For the 1591-92 mission, we have only sporadic testimonies in the Society's archives, viz-à-vis a letter in Latin from the Jesuit Reginault to Acquaviva dated November 11, 1591, sent from Pont-à-Mousson, about Father Bracanius, who died during this campaign, and two copies of letters in Latin from Acquaviva to the head of the mission, one dated November 9, 1591, and the other, February $15,1592 .{ }^{40}$ This paucity of testimonies is in part compensated for by the correspondence of the pontifical commissioner with the Segreteria di Stato. ${ }^{41}$ On August 25, 1591, Matteucci describes the excellent discipline of the soldiers during the journey from Italy to Lorraine ("they marched in good order"). ${ }^{42}$ However, at the beginning of autumn, difficulties

39 Boltanski, "Forger le 'soldat chrétien," 72-75; Gianclaudio Civale, Guerrieri di Cristo: Inquisitori, gesuiti e soldati alla battaglia di Lepanto (Milano: Unicopli, 2009); Olivier Chaline, La bataille de la Montagne Blanche (8 novembre 1620): Un mystique chez les guerriers (Paris: Vienot, 2000).

40 ARSI, Gall. 93, f. 31; Franc. 1-II, ff. 370, 373 .

41 Asv, Segreteria di Stato Francia, 38; to be integrated with Miscellanea, Arm., I, 24, and with other sources exploited by Cloulas, "L'armée pontificale."

42 Asv, Segreteria di Stato Francia, 38, f. 5 . 
of payment and food supply arise: an epidemic breaks out, entailing heavy casualties. In late October 1591, Matteucci reports the impossibility of providing bread and fodder; he mentions the murdering of soldiers in the rear by local peasants. He also explains that it was necessary to abandon a number of sick men at Verdun under the custody of the local bishop, who had required the assistance of an Italian-speaking canon and, in addition, of an Italian Capuchin, along with some other clerics from the peninsula. ${ }^{43}$ By the end of January 1592, the cavalry, initially composed by one thousand horsemen, was reduced to $45^{\circ}$ because of deaths and desertions; then, in mid-March, to 250, half of them unfit for active service, moving on foot, almost naked, and often unarmed, most of their officers having died or disappeared ${ }^{44}$ In the early summer, Matteucci had to dismiss the Swiss contingent, which had rebelled on several occasions and repeatedly threatened to disband if their pay was not forthcoming, in particular just before the siege of Rouen in April 1592. Even though the behavior of the Swiss contingent was somewhat extreme, ${ }^{45}$ it should be noted that, in 1591-92, several mutinies occurred in other Catholic armies. Finally, Matteucci had to get rid of the surviving Italian soldiers. As a result, the pontifical army was almost entirely recomposed, notably thanks to three thousand German foot soldiers under the command of Baron Boppard. It had been planned that these troops, augmented by two regiments of cavalry, would be amalgamated with the rest of the Catholic army when the duke of Parma was able to return to France; but this new campaign would be forestalled by Farnese's death on December 2, 1592. ${ }^{46}$

Farnese's army, moreover, was hampered by the paucity of food and fodder supplies, and by excessive delays in wage payments. After January 1592, as a result of disease and desertion, its size was greatly reduced, even if its overall condition remained viable. ${ }^{47}$ The description of the state of French troops sent by Matteucci is apocalyptic. According to him, in late January 1592, the French soldiers lacked even the most basic wherewithal; their only objective was to get their hands on some of the money they desperately needed; ${ }^{48}$ all kind of

\footnotetext{
43 Asv, Miscellanea, Arm., I, 24, ff. 339-40.

44 Asv, Segreteria di Stato Francia, 38, f. 6 (January 28, 1592); ff. 63-64 (March 24, 1592).

45 Asv, Segreteria di Stato Francia, 38, ff. 11, 21 (January 31, 1592); ff. 63-64, 216-17 (April 3, 1592); Miscellanea, Arm., I, 24, f. 358 (November 16, 1591); Cloulas, "L'armée pontificale," 9o, 92-94.

46 Asv, Segreteria di Stato Francia, 38, f. 239 (August 13, 1592); Cloulas, "L'armée pontificale," 97. See also Philippe Van Isacker, "Notes sur l'intervention militaire de Clément viII en France à la fin du XVI ${ }^{\mathrm{e}}$ siècle," Revue d'histoire ecclésiastique 12 (1911): 702-13.

47 Lloyd, Rouen Campaign, 176; Asv, Segreteria di Stato Francia, 38, f. 218.

48 Asv, Segreteria di Stato Francia, 38, f. 6 (January 28) and f. 20 (end of January 1592).
} 
discipline had vanished, their officers tolerated "a licentious way of life." The captains of the Holy League had not hesitated to leave the men they were in charge of with no resources and retire to their own castles in Champagne. ${ }^{49} \mathrm{In}$ May, the French cavalry disbanded, a thousand French horsemen making off on a single occasion. ${ }^{50}$

From 1590 to 1592, whatever their origins, the troops that were moving around France committed all kinds of violence and extortions. ${ }^{51}$ It is clear that the demands at the heart of the Jesuits' project of reform (the elimination of robbery and looting, the restitution of stolen goods, a strict discipline, the struggle against vice and sin) had little practical response among the foreign allies of the League or among the League forces themselves. So much is well documented in the reports and Matteucci's correspondence, as well as other testimony. In late January 1592, the pontifical commissioner describes the high frequency of theft of horses, mules, and baggage by the pope's army. Such stealing mainly concerned allied troops who should be "even more mistrusted than our enemies." The absence of any respect for the sacred, and, in particular, for religious objects, is specifically cited by Matteucci, who complains about the theft of the cross, the chalice, the candle holders, and other things necessary for his field chapel. The crowns and Agnus Dei, probably prepared for distribution to the soldiers, had been thrown on the ground and trodden upon. Matteucci had decided to walk at the side of the mules carrying the papal coins for the soldiers' pay to watch over them. The commissioner also reports the laxity of the captains in the pontifical army who failed to combat the Italian soldiers' abuses, such as selling their horses to the enemy and claiming that they have been stolen. ${ }^{52}$ Robbery was mainly directed against civilians, the exactions by the pope's soldiers already beginning in the duchy of Milan, before crossing the French border. ${ }^{53}$

In the fall of 1591, even before the arrival of the Farnese's army, Spanish and German soldiers raised, and expecting to be paid, by Philip II were already numerous in France, but they were left without any resources and began to

Asv, Segreteria di Stato Francia, 38, f. 20 (end of January 1592); see also Miscellanea, Arm., I, 24, f. 341 (October 28, 1591), extract of a letter and a report from Matteucci.

$50 \quad$ Asv, Segreteria di Stato Francia, 38, f. 125 (May 23, 1592).

51 See also Pallier, Recherches sur l'imprimerie, 179, who reports the "arrest" by the Parliament of Paris attempting, in vain, to regulate soldiers' exactions. In March 1593, Henri IV implements an ordonnance to discipline the fighters who commit robbery and murder: Denise Turrel, Le blanc de France: La construction des signes identitaires pendant les guerres de religion, 1562-1629 (Geneva: Droz, 2005), 43.

52 Asv, Segreteria di Stato Francia, 38, ff. 6-8, in particular f. 7 (January 28, 1592).

53 Cloulas, "L’armée pontificale," 86. 
suffer from starvation. This pushed them to live off the country, putting their hands on anything that might be consumed, going as far as to burn villages and farms. ${ }^{54}$ Later, the soldiers of Farnese would behave similarly. Matteucci accuses them of looting churches, raping nuns in their convents, and more generally of behaving like conquerors. ${ }^{55}$ It should be pointed out, however, that similar charges had already been leveled against Farnese's army, guilty of robbery of religious objects, molestation of clerics, and terrible violence directed against civilians in Flanders. ${ }^{56}$ In France, in the fall of 1590, the duke of Parma's army had acquired a reputation of great cruelty after the storming of Lagny and Corbeil, whose "royalist" garrisons had been massacred. The towns themselves had been ransacked. ${ }^{57}$ From then on, with macabre irony, "royalist" pamphlets would refer to Farnese by the nickname "Jean de Lagny," in memory of the treatment he had inflicted on the town. ${ }^{58}$

Regarding exactions, however, French soldiers were on a par with the foreign armies. In October 1591, deputies of the Paris League went to Reims to ask for the support of the Leaguer noble leaders. They expressed the complaints of the Parisian Leaguer oligarchy who denounced the soldiers' plundering, as well as the imposition of taxes near the capital. The Parisian Leaguers' grievances were directed against all soldiers, whichever faction they served (Holy League or "royalist"), and whatever their nationality..$^{59}$ Matteucci himself was not spared by his allies of the League, the duke of Mayenne showing a particular lack of regard for the pope's representative. In the summer of 1592, at the close of his mission in France, the commissioner was arrested at the insistence of the League's general lieutenant and sent to jail, so that his scheduled departure for Flanders had to be postponed. The Leaguers were probably trying to extract some money from him. ${ }^{60}$

54 ASv, Miscellanea, Arm., I, 24, f. 341 (October 28, 1591).

55 Asv, Segreteria di Stato Francia, 38, f. 19 (January 31, 1592).

56 Schoonjans, “Castra Dei," 528.

57 Bruslé de Montpleinchamp, L'histoire d'Alexandre Farnèze, 301-2; Journal historique de Pierre Fayet sur les troubles de la Ligue, ed. Victor Luzarche (Tours: Ladevèze, 1852), 98-99. See Nicolas Brûlart, Journal d'un ligueur parisien: Des barricades à la levée du siège de Paris par Henri IV, 1588-159o, ed. Xavier Le Person (Geneva: Droz, 1999), 192.

58 Pallier, Recherches sur l'imprimerie, 89.

59 ASv, Miscellanea, Arm., I, 24, ff. 475-76 (October 21, 1591).

6o Asv, Segreteria di Stato Francia, 38, f. 126 (June 2, 1592); f. 140 (July 4, 1592), copy of a letter of Filippo Sega; Cloulas, “L'armée pontificale," 96. 
The case of France in 1590-92 shows the capacity of the "Christian Soldier" model and of the military missions to adapt to different contexts of war. Two vectors seem to have favored the circulation and the dissemination of this project in time and space: firstly, in the early modern era, and at least until the Thirty Years' War, the close association of the project with an ideal of Holy War, reactivated and at the same time transformed over the European confessional conflicts; secondly, the link of these missions to the armies (and their particularities) with a broader, global, and universal missionary project embodied particularly by the Society of Jesus. In 1590-92, the "Christian Soldier" model was welcomed in France, as shown by numerous writings coming from the radical and urban circles of the League. The commitment of clerics close to soldiers and city militias in some Leaguer towns was strong, especially during a siege. However, a willingness to accept the model had no practical outcome in the creation of a structured religious guidance and care for the French forces of the League. Perhaps this was due to the way of thinking of the Leaguer radicals, attracted to the spirit of crusade and critical of the nobility which they saw as deficient in vertu. Consequently, even within the League, the noble leaders were moved to reject this model of Counter-Reformation war, a situation that may change when religious peace is established, after the edit de Nantes. Finally, on more practical level, in all military contingents, the project of the Jesuits ended in failure in the field of discipline and moral reform of the soldiers' behavior. This failure was largely the result of the terrible pressure of the intrinsic violence of war, which turned out to be an enduring obstacle difficult to overcome. 